\title{
PERBANDINGAN PERSENTASE VOLUME TERAS KAYU JATI CEPAT TUMBUH DAN KONVENSIONAL UMUR 7 TAHUN ASAL PENAJAM, KALIMANTAN TIMUR
}

\author{
(Heartwood Portion in Logs of 7 Years Old Fast Growing and \\ Conventional Teak Taken from Penajam, East Kalimantan)
}

\author{
Oleh/By :
}

Krisdianto \& Ginuk Sumarni ${ }^{1)}$

\begin{abstract}
Teak wood (Tectona grandis L.f.) has been popularly used as furniture and constructional timber. Fast growing teak has been developed using tissue-culture to increase supply from teak plantation. It is known as 'Jati super', 'Jati unggul', Jati prima' as well as 'Jati emas' or 'super teak.' However, there is lack of information about timber quality of teak. from this new generation. This study was aimed for analyzing heartwood portion as one parameter in determination of wood quality, between the 'super' and 'conventional teak'. Logs were taken from 7 year old stand that planted in the same site. The results showed that heartwood has been found in the 7 year old tree. Heartwood portion of jati super, was about $39.5 \%$, which is higher than that of conventional teak, which was about 20.3\%. According to SNI 01-5007.12003, both the super and conventional teak can be classified into small round logs (KBK, A.I.).
\end{abstract}

Keywords: Teak, super, conventional, heartwood

\begin{abstract}
ABSTRAK
Kayu jati (Tectona grandis L.f.) telah dikenal sebagai bahan baku mebel dan konstruksi dengan kualitas tinggi. Jati cepat tumbuh atau dikenal dengan nama dagang 'Jati super', 'Jati unggul', 'Jati prima' atau 'Jati emas' merupakan tanaman jati yang dikembangkan melalui kultur jaringan dan bertujuan menambah pasokan bahan baku kayu jati. Sedangkan kayu jati konvensional merupakan tanaman yang dikembangkan melalui perkecambahan biji. Informasi mengenai kualitas kayu jati cepat tumbuh belum diketahui. Salah satu parameter kualitas kayu jati dapat dilihat dari persentase kayu terasnya dalam batang. Penelitian ini bertujuan membandingkan persentase teras kayu jati super dan konvensional pada umur dan lokasi yang sama. Hasil pengamatan menunjukkan bahwa pada umur 7 tahun, kayu teras telah terbentuk pada seluruh lempengan kayu jati super maupun konvensional dari bagian ujung, tengah dan pangkal. Persentase kayu teras jati super rata-rata 39,6\%, lebih besar dari jati konvensional 20,3\%.
\end{abstract}

${ }^{1)}$ Peneliti pada Pusat Penelitian dan Pengembangan Hasil Hutan, Bogor 
Berdasarkan persentase kayu terasnya kayu jati konvensional lebih baik dari jati super. Namun, parameter kualitas kayu yang lain juga harus diperhatikan seperti kualitas serat, kandungan bahan kimia dan keawetan alaminya. Berdasarkan SNI 01-5007.1-2003, batang kayu jati super dan konvensional pada umur 7 tahun dapat masuk dalam kriteria kayu bulat kecil (KBK, A.I.).

Kata kunci: Jati, super, konvensional, persentase, teras

\section{PENDAHULUAN}

Kayu jati (Tectona grandis L.f.) atau 'teak wood' telah dikenal masyarakat nasional maupun internasional sebagai bahan baku industri pengolahan kayu yang memiliki banyak keunggulan. Selain mudah dikerjakan, kayu jati memiliki kelas kuat II dan kelas awet I - II (Oey Djoen Seng, 1964), sehingga memenuhi kriteria yang ideal sebagai bahan baku bagi produk kayu olahan seperti mebel dan konstruksi.

Kualitas kayu jati yang menonjol menempatkan produk kayunya dalam tingkatan mahal dan mewah. Melihat kualitas kayu jati yang lebih baik dari kayu jenis lain maka persepsi masyarakat tersebut sangat beralasan. Dalam kondisi demikian, permintaan masyarakat terhadap produk dari kayu jati meningkat dari waktu ke waktu.

Meningkatnya permintaan produk kayu jati dari dalam negeri maupun untuk ekspor menyebabkan peningkatan kebutuhan kayu jati untuk produk olahan. Namun demikian, saat ini pasokan kayu jati untuk industri pengolahan kayu mengalami penurunan. Salah satu penyebabnya adalah umur panen kayu jati yang sangat panjang, yaitu minimal 45 tahun, sehingga selain pasokannya kurang, harganyapun menjadi mahal karena rotasi tanaman yang terlalu panjang.

Untuk menambah pasokan kayu jati yang semakin menipis, saat ini Perum Perhutani dan beberapa perusahaan swasta telah mengembangkan pohon jati cepat tumbuh. Jati cepat tumbuh mempunyai masa panen lebih cepat yaitu antara 15 - 20 tahun. Jati cepat tumbuh dikenal dengan nama jati super, jati unggul, jati prima atau jati emas. Pada dasarnya pemberian nama jati cepat tumbuh tersebut bergantung pada perusahaan yang memberikan nama produk bibit jati cepat tumbuh. Bibit jati cepat tumbuh ini berasal dari pohon-pohon induk terpilih dan diperbanyak melalui kultur jaringan. Tanaman jati cepat tumbuh diharapkan memiliki pertumbuhan 3 - 4 kali lebih cepat dari jati konvensional. Sedangkan jati konvensional adalah tanaman jati yang perbanyakannya berasal dari biji. Jati konvensional umumnya percabangan lebih sedikit dan batangnya lurus (Bachri, 2001).

Permasalahan mendasar saat ini adalah masyarakat pengguna kayu belum mengetahui kualitas kayu jati cepat tumbuh. Kenyataan ini didasarkan pada pemikiran bahwa pertumbuhan pohon yang cepat akan menghasilkan sel-sel yang lebih pendek sehingga mengurangi kualitas kayunya (Brown et al., 1994). Salah satu parameter penilaian kualitas kayu adalah terbentuknya kayu teras dalam batang pohon. Penelitian ini mempunyai tujuan membandingkan persentase kayu teras jati cepat tumbuh dengan konvensional pada umur yang sama. 


\section{BAHAN DAN METODE}

\section{A. Lokasi Pengambilan Contoh Uji}

Kayu jati cepat tumbuh dan konvensional berumur 7 tahun yang berasal dari petak sama yang ditanam oleh PT Monfori Nusantara di areal PT ITCI Kartika Utama, Penajam, Kalimantan Timur.

Dari setiap tegakan diambil 3 lempengan (disk) dengan ketebalan $\pm 5 \mathrm{~cm}$ yang mewakili bagian pangkal, tengah dan ujung. Dari setiap lempengan tipis (disk) dilakukan pengukuran persentase kayu teras, gubal, empulur dan bagian kulitnya.

\section{B. Metode Pengukuran Persentase Kayu Teras}

Pengukuran persentase kayu teras dilakukan berdasarkan pengukuran yang telah dilakukan oleh Wahyudi dan Arifien (2005). Sebelum diukur, penampang lintang disk diampelas untuk memperoleh batas yang jelas antara bagian teras, gubal, empulur dan kulitnya. Gambaran penampang lintang tersebut dipolakan di atas plastik transparansi dan kemudian diukur jari-jari total $(\mathrm{R})$, tebal kulit $(\mathrm{k})$ dan panjang jari-jari kayu sampai bagian teras (r) serta empulurnya (e). Dalam setiap lempengan dilakukan 4 kali pengukuran, yaitu pada $R$ terpanjang dan terpendek serta dua diantaranya. Perhitungan volume kayu total dan terasnya adalah :

\section{Volume kayu total (total wood volume, $\left.\mathrm{mm}^{3}\right)=\left[\pi(\mathrm{R}-\mathrm{k})^{2}\right] \mathrm{t}$ \\ Volume kayu teras (heartwood volume, $\left.\mathrm{mm}^{3}\right)=\left[\pi(\mathrm{r}-\mathrm{e})^{2}\right] \mathrm{t}$}

di mana: $\mathrm{R}=$ jari-jari total (total rang, $\mathrm{mm}$ )

$\mathrm{K}=$ tebal kulit (bark, thickness, $\mathrm{mm}$ )

$\mathrm{r}=$ jari-jari kayu teras (heartwood rang, $\mathrm{mm}$ )

$\mathrm{e}=\operatorname{empulur}($ ith, $\mathrm{mm}$ )

$\mathrm{t}=$ tebal lempengan (disc thickness, $\mathrm{mm}$ )

Dari perhitungan volume tersebut, diperhitungkan persentase kayu teras dari total volume kayu dalam lempengannya sebagai berikut:

$$
\text { Kayu teras (Heartwood portion, \%) }=\frac{\text { Volume kayu teras (Heartwood volume) }}{\text { Volume kayu total (Total wood volume) }} \times 100 \%
$$

\section{Analisa Data}

Data persentase kayu teras dianalisa secara factorial, dengan faktornya jenis jati, yaitu super dan konvensional, serta posisi contoh uji, yaitu ujung, tengah dan pangkal.

\section{HASIL DAN PEMBAHASAN}

Secara umum, hasil pengamatan menunjukkan bahwa, seluruh lempengan telah terbentuk kayu teras meskipun sedikit. Dalam sebuah lempengan, warna coklat tua dipisahkan secara jelas oleh gubal yang berwarna lebih muda (Gambar 1). Kayu teras 
berdasarkan definisi Jane (1970) adalah bagian batang yang mempunyai warna lebih tua dan terdiri dari sel-sel yang telah mati.

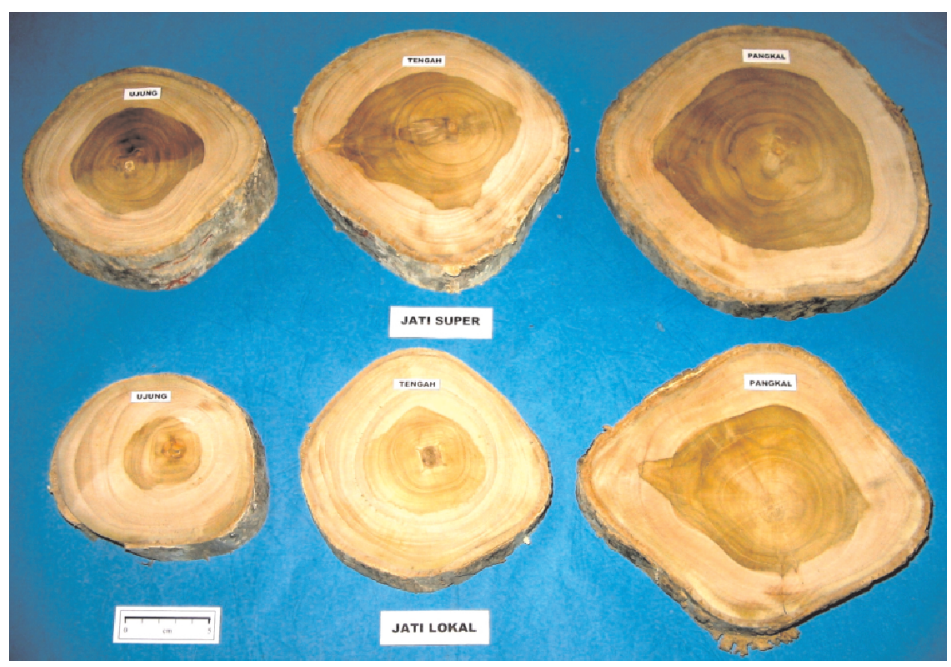

\section{Gambar 1. Lempengan kayu jati super (atas) dan konvensional (bawah) Figure 1. Super teak discs (top) and conventional teak discs (down)}

Hasil pengukuran jari-jari, penghitungan volume dan persentase teras kayu jati super dan konvensional ditampilkan dalam Tabel 1.

Tabel 1 menunjukkan bahwa rata-rata kulit dan empulur kayu jati super lebih tebal dari kayu jati konvensional. Kecenderungan kulitnya adalah dari bagian pangkal paling tebal dan menipis ke bagian ujungnya. Hal ini berlaku sebaliknya untuk empulur, yaitu empulur bagian ujung pohon paling tebal dan menipis ke arah pangkal pohonnya.

Selain hasil pengukuran tebal kulit dan empulur, Tabel 1 juga menunjukkan persentase teras kayunya. Persentase teras kayu jati super lebih tinggi dari kayu jati konvensional. Ratarata teras kayu jati super adalah 39,6\% sementara jati konvensional hanya 20,3\%. Persentase kayu teras jati super hampir dua kali lipat lebih tinggi dari kayu jati konvensional. Dari enam pohon, yaitu tiga pohon jati super dan tiga pohon jati konvensional yang dipelajari dari lokasi penanaman yang sama menunjukkan bahwa pembentukan teras kayu jati super lebih banyak dibandingkan kayu jati konvensional. Dari pengamatan di lapangan menunjukkan bahwa dalam satu petak uji coba, pertumbuhan pohon jati super lebih baik dari jati konvensional (Gambar 2). 
Tabel 1. Persentase kayu teras dalam lempengan kayu jati super dan konvensional Table 1. Heartwood portion of super and conventional teak discs wood

\begin{tabular}{|c|c|c|c|c|c|c|c|c|c|}
\hline $\begin{array}{l}\text { Jenis pohon Jati } \\
\text { (Teak species) }\end{array}$ & \begin{tabular}{|c|} 
Bagian \\
contoh \\
uji \\
$($ Sample \\
location $)^{*}$ \\
\end{tabular} & $\begin{array}{c}\text { Tebal } \\
\text { kulit } \\
\text { (Bark } \\
\text { thickness) }\end{array}$ & $\begin{array}{c}\begin{array}{c}\text { Diameter } \\
\text { empulur } \\
\text { (Pith } \\
\text { diameter) }\end{array} \\
\end{array}$ & \begin{tabular}{|c} 
Jari-jari \\
total \\
(Total spoke, \\
$\mathrm{R})^{* *}$
\end{tabular} & $\begin{array}{c}\text { Jari-jari } \\
\text { kayu teras } \\
(\text { Heartwood } \\
\text { spoke, r) })^{* * *}\end{array}$ & \begin{tabular}{|c|} 
Tebal \\
lempengan \\
(Disks \\
thickness)
\end{tabular} & \begin{tabular}{|c|} 
Volume \\
teras \\
(Heartwood \\
volume $)$
\end{tabular} & $\begin{array}{l}\text { Volume total } \\
\text { Lempengan } \\
\text { (Disks volume) }\end{array}$ & $\begin{array}{c}\text { Persentase } \\
\text { teras } \\
\text { (Heartwood } \\
\text { Portion) }\end{array}$ \\
\hline & & $\mathrm{mm}$ & $\mathrm{mm}$ & $\mathrm{mm}$ & $\mathrm{mm}$ & $\mathrm{mm}$ & $\mathrm{mm}^{3}$ & $\mathrm{~mm}^{3}$ & $\%$ \\
\hline $\begin{array}{l}\text { Super-1 } \\
\text { (Super-1) }\end{array}$ & $\mathrm{U}$ & 3,9 & 8,8 & 52,9 & 30,5 & 48,4 & $141.477,4$ & $426.354,0$ & 33 \\
\hline $\begin{array}{l}\text { Super-1 } \\
\text { (Super-1) }\end{array}$ & $\mathrm{T}$ & 4,4 & 7,9 & 66,2 & 39,7 & 51,9 & $257.192,2$ & $714.628,0$ & 36 \\
\hline $\begin{array}{l}\text { Super-1 } \\
\text { (Super-1) }\end{array}$ & $\mathrm{P}$ & 5,1 & 3,8 & 80,2 & 61,7 & 48,3 & $583.739,6$ & $977.175,7$ & 60 \\
\hline $\begin{array}{l}\text { Super-2 } \\
\text { (Super-2) }\end{array}$ & $\mathrm{U}$ & 4,1 & 8,4 & 52,2 & 31,9 & 53,2 & $171.104,9$ & $454.658,9$ & 38 \\
\hline $\begin{array}{l}\text { Super-2 } \\
\text { (Super-2) }\end{array}$ & $\mathrm{T}$ & 4,8 & 5,8 & 64,0 & 39,4 & 46,4 & $228.445,7$ & $597.258,3$ & 38 \\
\hline $\begin{array}{l}\text { Super-2 } \\
\text { (Super-2) }\end{array}$ & $\mathrm{P}$ & 5,0 & 2,4 & 85,1 & 58,7 & 41,1 & $442.443,2$ & $934.885,7$ & 47 \\
\hline $\begin{array}{l}\text { Super-3 } \\
\text { (Super31) }\end{array}$ & $\mathrm{U}$ & 4,1 & 10,5 & 55,1 & 29,1 & 45,5 & $119.816,4$ & $433.674,7$ & 28 \\
\hline $\begin{array}{l}\text { Super-3 } \\
\text { (Super-3) }\end{array}$ & $\mathrm{T}$ & 4,8 & 9,1 & 65,6 & 38,2 & 51,1 & $237.435,3$ & $691.131,3$ & 34 \\
\hline $\begin{array}{l}\text { Super-3 } \\
\text { (Super-3) }\end{array}$ & $\mathrm{P}$ & 5,0 & 6,28 & 76,4 & 49,6 & 51,5 & $396.703,3$ & $944.527,3$ & 42 \\
\hline $\begin{array}{l}\text { Rata-rata } \\
\text { (average) }\end{array}$ & & 4,6 & 6,9 & & & & & & 39,6 \\
\hline $\begin{array}{l}\text { Konvensional-1 } \\
\text { (Conventional-1) }\end{array}$ & $\mathrm{U}$ & 2,8 & 10,9 & 47,6 & 15,1 & 47,7 & $34.221,1$ & $339.722,8$ & 10 \\
\hline $\begin{array}{l}\text { Konvensional-1 } \\
\text { (Conventional-1) }\end{array}$ & $\mathrm{T}$ & 3,5 & 8,9 & 57,2 & 33,8 & 41,5 & $152.103,9$ & $427.239,9$ & 36 \\
\hline $\begin{array}{l}\text { Konvensional-1 } \\
\text { (Conventional-1) }\end{array}$ & $\mathrm{P}$ & 4,5 & 2,9 & 76,5 & 48,6 & 47,3 & $349.897,5$ & $869.386,4$ & 40 \\
\hline $\begin{array}{l}\text { Konvensional-2 } \\
\text { (Conventional-2) }\end{array}$ & $\bar{U}$ & 2,8 & 12,1 & 39,4 & 13,8 & 44,2 & $26.961,8$ & $215.331,9$ & 13 \\
\hline $\begin{array}{l}\text { Konvensional-2 } \\
\text { (Conventional-2) }\end{array}$ & $\mathrm{T}$ & 3,5 & 10,4 & 54,1 & 25,0 & 45,1 & $89.082,2$ & $413.751,3$ & 21 \\
\hline $\begin{array}{l}\text { Konvensional-2 } \\
\text { (Conventional-2) }\end{array}$ & $\mathrm{P}$ & 4,7 & 2,1 & 66,8 & 44,0 & 58,3 & $356.249,4$ & $816.760,3$ & 43 \\
\hline $\begin{array}{l}\text { Konvensional-3 } \\
\text { (Conventional-3) }\end{array}$ & $\mathrm{U}$ & 3,0 & 9,4 & 40,6 & 7,2 & 47,7 & $7.760,2$ & $246.579,5$ & 3 \\
\hline $\begin{array}{l}\text { Konvensional-3 } \\
\text { (Conventional-3) }\end{array}$ & $\mathrm{T}$ & 3,6 & 7,9 & 49,1 & 11,7 & 45,4 & $19.817,4$ & $343.950,5$ & 5 \\
\hline $\begin{array}{l}\text { Konvensional-3 } \\
\text { (Conventional-3) }\end{array}$ & $\mathrm{P}$ & 4,8 & 3,9 & 60,6 & 19,3 & 48,8 & $57.600,6$ & $564.262,2$ & 10 \\
\hline $\begin{array}{l}\text { Rata-rata } \\
\text { (average) }\end{array}$ & & 3,7 & 7,6 & & & & & & 20,3 \\
\hline
\end{tabular}

Keterangan (Remarks) : * $\mathrm{U}=\mathrm{Ujung}\left(\right.$ Top), $\mathrm{T}=$ Tengah (Middle), $\mathrm{P}=$ Pangkal (Bottom); ${ }^{* *}$ Tanpa kulit (Without bark); ***'Tanpa empulur (Withoutpith) 


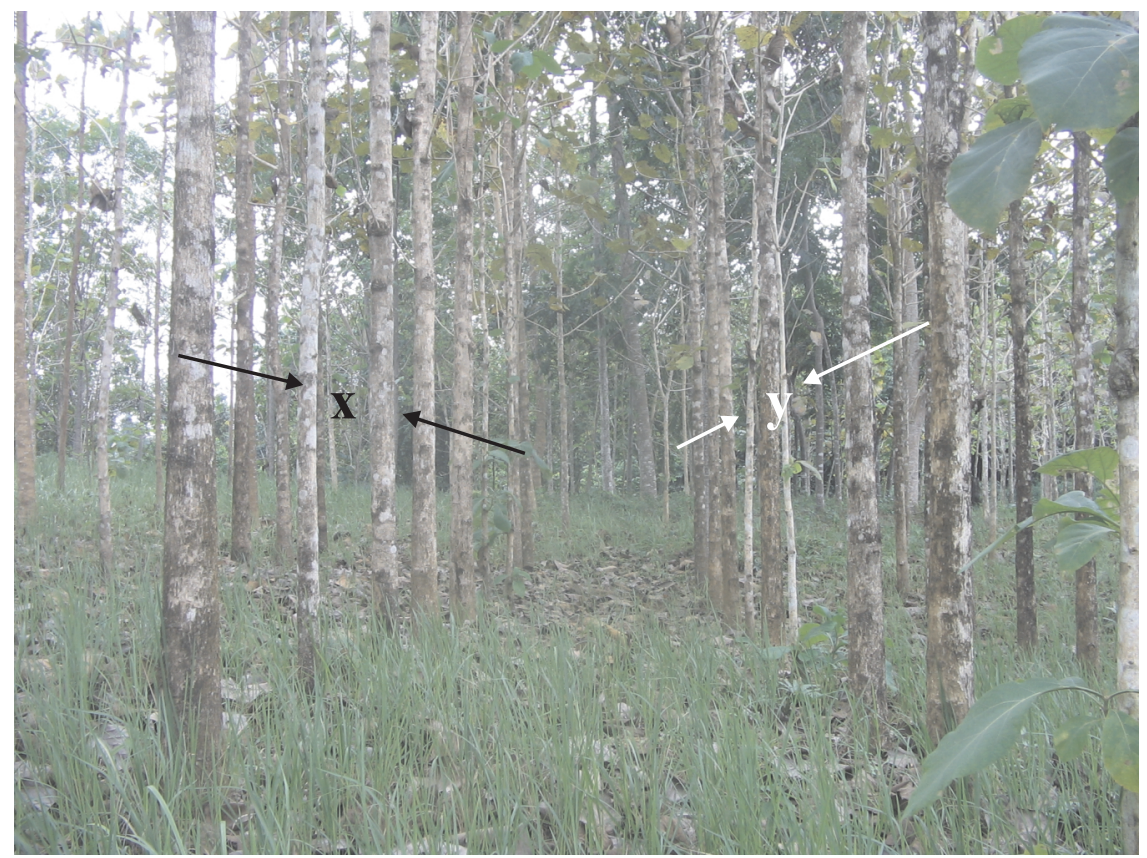

Gambar 2. Pohon jati super (X) dan jati konvensional (Y) dalam satu petak uji coba Figure 2. Super $(X)$ and conventional $(Y)$ teak plants from one test site

Selain perbedaan kandungan teras kayu jati super dan konvensional, dijumpai pula perbedaan kandungan teras dari bagian pangkal, tengah dan ujung. Dalam satu pohon, persentase terbesar kayu teras dijumpai pada lempengan bagian pangkal, sedangkan bagian ujung, persentase kayu terasnya paling kecil. Pola ini dijumpai tidak hanya pada kayu jati super, tetapi juga pada kayu jati konvensional. Pola persentase kayu teras ditunjukkan pada grafik Gambar3.

Besarnya persentase kayu teras di bagian pangkal merupakan kenyataan bahwa sel-sel kayu di bagian pangkal batang lebih tua dibandingkan bagian tengah dan ujungnya, sehingga di bagian pangkal persentase terasnya lebih besar dari tengah dan ujungnya.

Selain pembentukan kayu teras lebih besar, bagian pangkal batang juga mempunyai jaringan lunak empulur yang paling sedikit. Empulur merupakan jaringan lunak yang akan mengeras pada saat batang tumbuh dewasa (Gambar 4). Empulur semakin membesar diameternya searah tinggi pohon, dengan kata lain semakin tinggi pohon, maka bagian empulurnya semakin besar (Wilson and White, 1986). 


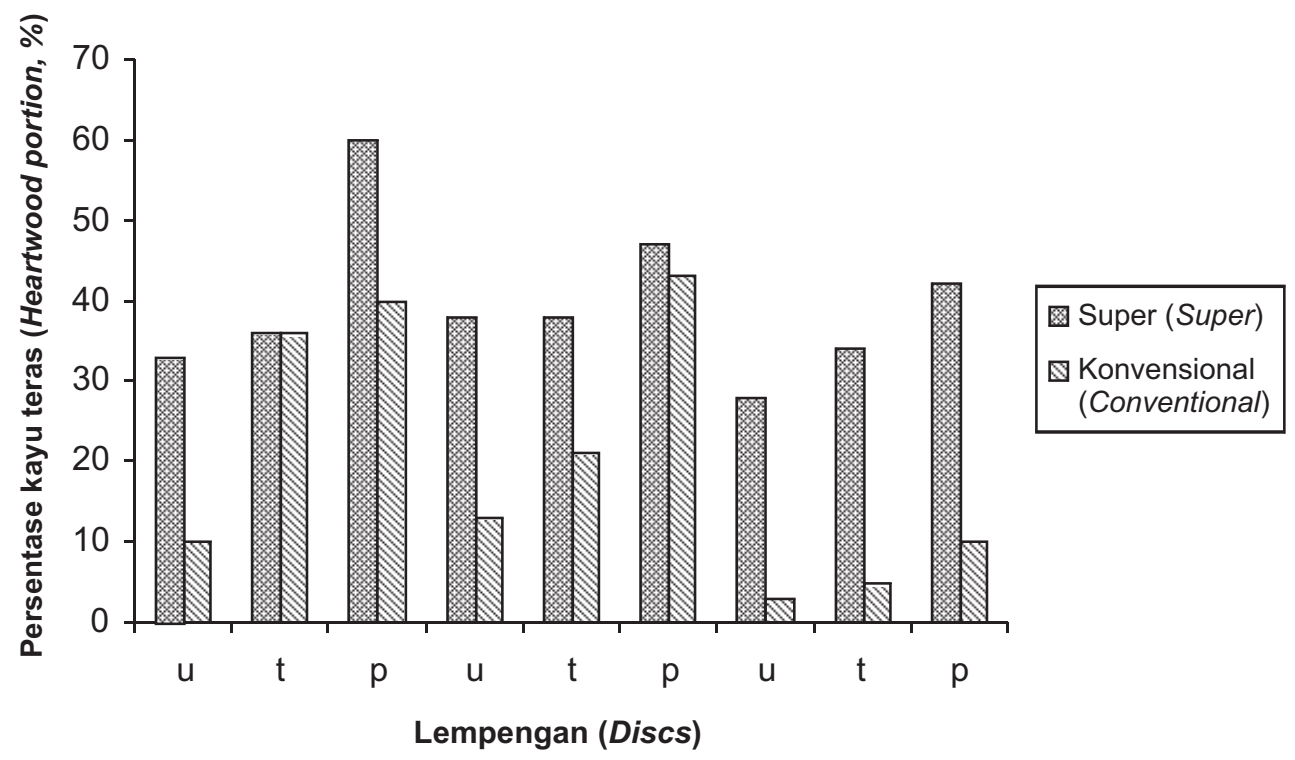

\section{Gambar 3. Pola persentase kayu teras pada lempengan yang diamati Figure 3. Heartwood portion of the observed discs}

Keterangan $($ Remarks $): \mathrm{u}=\operatorname{ujung}($ top $), \mathrm{t}=$ tengah $($ middle $), \mathrm{p}=$ pangkal $($ bottom $)$

Berdasarkan pengukuran dan perhitungan kandungan teras dalam Tabel 1, hasil analisa sidik ragam ditampilkan dalam Tabel 2.

Dari pengujian statistik diperoleh kesimpulan bahwa kandungan teras kayu jati super berbeda nyata dengan kandungan teras jati konvensional. Selain itu, kandungan teras bagian ujung, tengah dan pangkal berbeda secara nyata pada tingkat kepercayaan 95\% dan 99\%. Uji lanjutan dengan Tukey, menunjukkan bahwa bagian pangkal berbeda nyata dengan bagian ujung pada tingkat kepercayaan 95\%, tetapi kandungan teras bagian pangkalnya tidak berbeda nyata dengan bagian tengah. Demikian pula kandungan teras bagian ujung tidak berbeda nyata dengan bagian tengahnya.

Kayu teras merupakan penumpukan sel-sel yang telah mati dan secara fisiologis selnya sudah tidak berfungsi. Kayu teras berwarna lebih tua dari bagian gubalnya, karena kandungan zat ekstraktif dalam kayu teras lebih tinggi (Gambar 4). Zat ekstraktif mempunyai fungsi penting dalam menjaga keawetan alami kayu, sehingga tidak mudah terserang organisme perusak kayu. Dalam hal ini, kayu teras lebih tahan terhadap serangan organisme perusak kayu dari pada kayu gubalnya (Butterfield, 1993). Teras kayu jati memiliki zat ekstraktif tektokinon yang diduga meningkatkan keawetan kayu jati terhadap serangan serangga perusak kayu. 

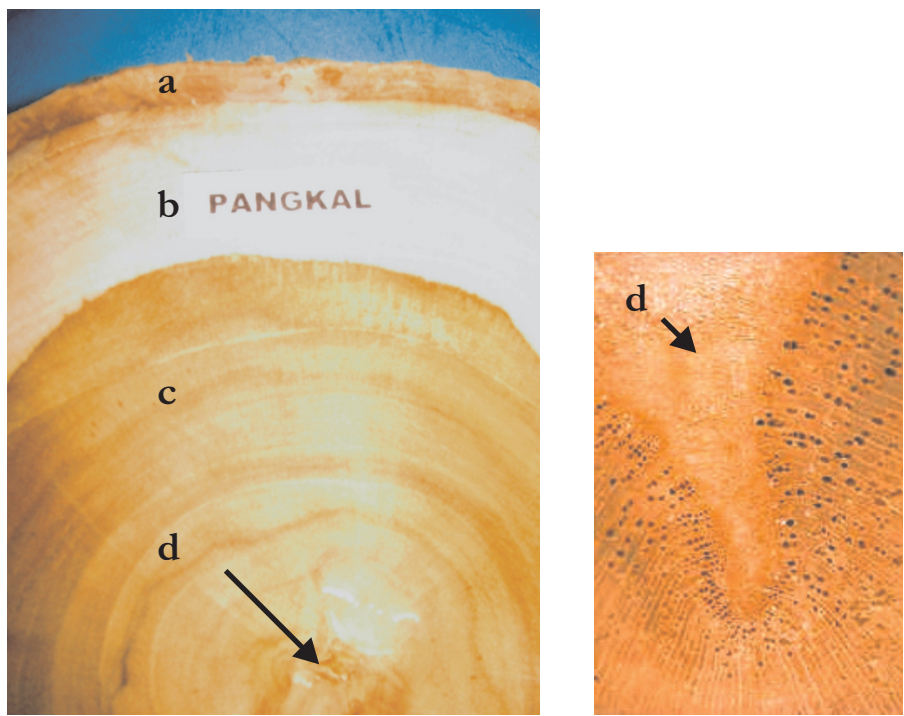

Gambar 4. Bagian batang kayu jati

Figure 4. Stem parts of teak wood

Keterangan (Remarks) : a. Kulit (Bark), b. Gubal (Sapwood), c. Teras (Heartwood) dan d. Empulur (Pith)

Tabel 2. Analisis sidik ragam

Table 2. Analysis of variance

\begin{tabular}{|l|c|c|c|c|}
\hline \multicolumn{1}{|c|}{$\begin{array}{c}\text { Sumber } \\
\text { (Source) }\end{array}$} & $\begin{array}{c}\text { Derajat bebas } \\
\text { (Degree of freedom) }\end{array}$ & $\begin{array}{c}\text { Jumlah Kuadrat } \\
\text { (Mean Square) }\end{array}$ & $\begin{array}{c}\text { F Tabel } \\
\text { (F from table) })\end{array}$ & $\begin{array}{c}\text { F hitung } \\
\text { (F counted) }\end{array}$ \\
\hline Jenis jati (Teak species) & 1 & 1701,389 & 161,4 & $14,277 * *$ \\
Posisi contoh (Sample position) & 2 & 580,500 & 18,51 & $4,871 * *$ \\
Jenis - posisi contoh & 2 & 31,056 & 18,51 & $0,261 * *$ \\
(Teak species vs sample position) & 12 & 119,167 & & \\
Error & 17 & & & \\
Total & & & \\
\hline
\end{tabular}

Keterangan (Remarks) : ** berbeda nyata pada tingkat kepercayaan 95\% dan 99\% (significantly different in $95 \%$ and $99 \%$ level of confidence)

Kayu teras terbentuk setelah beberapa tahun pertumbuhan pohon. Kayu teras berkembang secara perlahan ke arah lebar dan ujung pohon. Semakin tua umur pohon kayu terasnya semakin besar. Selain keawetan alaminya tinggi, warna coklat tua kayu teras sangat menarik terutama untuk bahan baku mebel, venir indah dan kerajinan. Selain warnanya lebih tua, kayu teras juga memiliki bau yang lebih tajam dari gubalnya yang disebabkan penimbunan zat ekstraktif dalam kayu terasnya. Pembentukan kayu teras dalam batang pohon diduga disebabkan penumpukan zat polyphenol dan pengurangan kadar air dalam sel-selnya (Butterfield, 1993). 


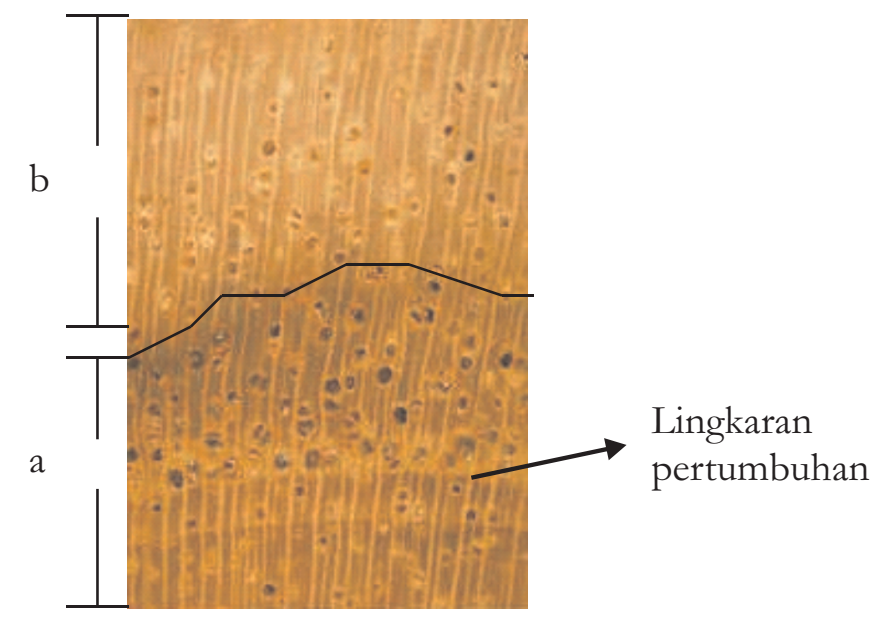

\section{Gambar 5. Peralihan kayu teras (a) dan kayu gubal (b) Figure 5. Transitional area between beartwood (a) and sapwood (b)}

Apabila dibandingkan dengan kayu jati konvensional yang telah berumur 45 tahun ke atas, maka warna kayu teras pada jati super dan konvensional lebih muda. Hal ini disebabkan kayu yang terbentuk selama kurang dari 10 tahun merupakan kayu muda atau juvenil wood (Wahyudi dan Arifien, 2005). Berdasarkan warna kayu teras yang lebih muda, maka diasumsikan kandungan zat ekstraktif teras kayu jati super dan konvensional 7 tahun lebih sedikit dari jati konvensional berumur 45 tahun ke atas. Dalam hal ini, kayu jati muda lebih mudah terserang organisme perusak kayu dibandingkan kayu jati konvensional yang lebih tua.

Dalam Standar Nasional Indonesia (SNI) 01-5007.17-2001 tentang pengukuran dan tabel isi kayu bundar jati, terdapat tiga kriteria sortimen, yaitu kayu bundar dengan ukuran diameter $30 \mathrm{~cm}$ atau lebih (KBB/A.III), kayu bundar dengan ukuran diameter $21 \mathrm{~cm}$ sampai dengan kurang dari $30 \mathrm{~cm}$ (KBS/A.II) dan kayu bundar dengan ukuran diameter kurang dari $21 \mathrm{~cm}$ atau KBK/A.I (Anonim, 2001). Rata-rata diameter bagian pangkal kayu jati super tanpa kulit adalah 16,1 cm, sedangkan kayu jati konvensional adalah 13,5 cm. Dalam standar pengukuran tersebut, keduanya termasuk dalam kelas diameter dibawah $21 \mathrm{~cm}$ dan dimasukkan dalam sortimen Kayu Bulat Kecil (KBK A.I.).

Walaupun batang kayu jati super dan konvensional masuk dalam kategori KBK A.I., namun perlu diperhatikan standar perlakuan dan penilaian mutu batangnya. Perlakuan yang ditetapkan oleh Perum Perhutani adalah peneresan batang jati sebelum ditebang, dalam hal ini kualitas kayu meningkat seiring dengan proses peneresan, sehingga kayu yang dihasilkan mirip dengan mutu batang dari Perum Perhutani. Selain itu, penilaian mutu batang harus disesuaikan dengan cacat yang ada dalam batang, diantaranya pecah/belah, pecah banting, pecah lepas/slemper, lubang gerek besar, inger-inger dan mata kayu (Anonim, 2001). 


\section{KESIMPULAN}

1. Jati cepat tumbuh atau dikenal dengan nama dagang 'Jati super', 'Jati unggul', Jati prima' atau 'Jati emas' merupakan tanaman jati yang dikembangkan melalui kultur jaringan dan bertujuan menambah pasokan kayu jati untuk bahan mebel dan konstruksi.

2. Pada umur 7 tahun, kayu teras telah dijumpai pada seluruh lempengan kayu jati bagian ujung, tengah dan pangkal, dengan persentase kayu teras terbesar pada bagian pangkal pohon.

3. Persentase kayu teras jati super 39,6\%, lebih besar dari jati konvensional yang hanya berkisar 20,3\%. Berdasarkan persentase kayu terasnya pada umur dan tempat tumbuh yang sama, kayu jati super lebih baik kualitas kayunya dari kayu jati konvensional. Namun demikian, parameter kualitas kayu lainnya seperti kualitas serat, keawetan alami dan kandungan bahan kimianya perlu diteliti.

4. Batang kayu jati super dan konvensional pada umur 7 tahun dapat masuk dalam kriteria kayu bulat kecil (KBK, A.I.).

\section{DAFTAR PUSTAKA}

Bachri, S. 2001. Jati super andalan hari tua. http://www.mitrabisnis.com/1301/11301a.htm. Didownload 5 November 2005.

Anonim. 2001. Pengukuran dan tabel isi kayu bundar jati. Badan Standarisasi Nasional, Jakarta. Standar Nasional Indonesia 01-5007.17-2001.

Brown, H.P., A.J. Panshin, C.C. Forsaith. 1994. Textbook of Wood Technology Vol.I. McGraw-Hill Book Company Inc. 4th Edition. New York.

Butterfield, B.G. 1993. The structure of wood: an overview. Chapter dalam J.C.F. Walker (Ed.) Prymary Wood Processing, Principles and Practice. Chapman and Hall. Melbourne.

Haygreen, J.G., J.L. Bowyer. 1996. Forest Products and Wood Science: An Introduction. 3rd edition. Ames IA, IOWA State University Press. Iowa.

Jane, F.W. 1970. The Structure of Wood, 2nd edition. Adam and Charles Black. London.

Oey Djoen Seng. 1964. Berat jenis dari jenis-jenis kayu Indonesia dan pengertian beratnya kayu untuk keperluan praktek. Pengumuman No.13. Puslitbang Hasil Hutan. Bogor.

Wahyudi, I. dan A.F. Arifien. 2005. Perbandingan struktur anatomis, sifat fisis dan sifat mekanis kayu jati unggul dan kayu jati konvensional. Jurnal Ilmu dan Teknologi Kayu Tropis 3(2):53-59. Bogor.

Wilson K. and D.J.B. White. 1986. The Anatomy of Wood: Its Diversity and Variability. Stobart and Son Ltd. London. 